\title{
AMOBILISASI ENZIM BROMELIN DARI BONGGOL NANAS DENGAN BAHAN PENDUKUNG (SUPPORT) KARAGENAN DARI RUMPUT LAUT (Euchema cottonii)
}

\author{
Wuryanti \\ Staf Pengajar Jurusan Kimia FMIPA Universitas Diponegoro.
}

\begin{abstract}
ABSTRAK
Bromelin adalah enzim proteolitik yang terdapat pada tananam nanas (Ananas comosus L) Telah dilakukan amobilisasi bromelin dari bonggol nanas. Amobilisasi dilakukan dengan metode penjebakan dengan polimer karagenan. Penentuan unit aktifitas dengan substrat kasein dan penentuan kadar protein dengan metoda Lowry. Enzim bromelin dari bonggol nanas bebas mempunyai kondisi waktu inkubasi optimum 5 menit, suhu optimum $35^{\circ} \mathrm{C}$, pH optimum 6,0 dengan aktifitas spesifik 7,215 U/mg. Setelah amobilisasi enzim bromelin bonggol nanas amobil memiliki waktu inkubasi optimum 5 menit, suhu optimum $33^{\circ} \mathrm{C}$, pH optimum 6,5 dengan aktivitas spesifik 7,215 U/mg. Pada pemakaian pertama aktifitas spesifik 7,215 U/mg, pada pemakaian kedua 7,215 U/mg, pada pemakaian ketiga 7,020 U/mg. Stabilitas enzim bromelin bonggol nanas amobil dapat dipertahankan hingga dua kali pemakaian.

Kata kunci: Bromelin, enzim, amobilisasi, aktivitas spesifik
\end{abstract}

\section{AMMOBILIZATION OF ENZYME BROMELIN FROM PINEAPPLE STEM WITH SEAWEED (Euchema cottonii) CARRAGEENAN AS A SUPPORT MATRIX}

\begin{abstract}
Bromelin is proteolytic enzyme contained in pineapple (Ananas comosus L.) Immobilized enzyme from the pineapple stem had been done. On this method enzyme is entrapped by carrageenan as a support matrix. Unit activity test with casein substrate and protein contain test with Lowry method. The research result that pineapple stem bromelin enzyme have optimum incubation time of 5 minutes, optimum temperature at $35{ }^{\circ} \mathrm{C}$, optimum $\mathrm{pH}$ at 6.0 with specific activity $7.215 \mathrm{U} / \mathrm{mg}$. After immobilization bromelin have optimum incubation time of 5 minutes, optimum temperature at $33^{\circ} \mathrm{C}$, and optimum pH at 6.5 with specific activity of $7.215 \mathrm{U} / \mathrm{mg}$. Immobilization enzyme stability maintained to twice utilization.
\end{abstract}

Keyword : Bromelin, Enzyme, Ammobilization, specific activity

\section{PENDAHULUAN}

Enzim merupakan unit protein fungsional yang berperan mengkatalisis reaksi-reaksi dalam metabolisme sel dan reaksi-reaksi lain dalam tubuh. Spesifikasi enzim terhadap substratnya teramat tinggi dalam mempercepat reaksi kimia tanpa produk samping (Lehninger, 1982).

\section{Bromelin}

Banyak varietas nanas (Pineapple, Ananas comosus L) yang termasuk dalam family bromeliaseae mengandung enzim proteolitik yang disebut bromelin 2 (Hui, 1992). Enzim ini menguraikan protein dengan jalan memutuskan ikatan peptida dan menghasilkan protein yang lebih sederhana (Sumarno, 1983). Enzim bromelin terdapat dalam semua jaringan tanaman nanas. Sekitar setengah dari protein dalam nanas mengandung protease bromelin. Di antara berbagai jenis buah, nanas merupakan sumber protease dengan konsentrasi tinggi dalam buah yang masak (Donald, tanpa tahun)

Bromelin bonggol nanas memiliki sifat karakteristik (Mantell $d k k$, 1985), (Reed, 1966), (Anonim, 2000) sebagai berikut: 
a. berat molekul $: 33.500$

b. titik isoelektrik : pH 9,55

c. $\mathrm{pH}$ optimum $: 6-8$

d. suhu optimum $\quad: 50{ }^{\circ} \mathrm{C}$

e. aktivitas spesifik : 5-10 U/mg protein.

f. Warna: putih sampai kekuning-kuningan dengan bau khas.

Bromelin merupakan unsur pokok dari nanas yang penting dan berguna dalam bidang farmasi dan makanan (Donald, tanpa tahun). Fungsi bromelin mirip dengan papain dan fisin, sebagai pemecah protein. Pada akhir-akhir ini enzim bromelin lebih banyak digunakan untuk penjernihan bir (chillpoofing bir) dan pengempukan daging (Anonim, 2000). Selain itu enzim bromelin sering pula dimanfaatkan sebagai bahan kontrasepsi KB untuk memperjarang kehamilan. Ibu-ibu yang sedang mengandung tidak dianjurkan makan nanas karena dapat mengakibatkan keguguran (Harianto, 1996).

Kegunaan lain dari bromelin adalah untuk memperlancar pencernaan protein, menyembuhkan artritis, sembelit, infeksi saluran pernafasan, luka atletik (pada kaki), angina, dan trauma (Wirakusumah, 1999).

\section{Amobilisasi Enzim}

Amobilisasi enzim artinya enzim dibatasi atau terlokalisir sehingga enzim dapat digunakan secara kontinyu. Masalah yang menarik agar enzim diamobilisasi jika jumlah substrat sangat besar dan enzim yang digunakan mahal (James, $d k k$, 1977). Keuntungan enzim yang diamobilisasi adalah enzim dapat dipisahkan dari campuran reaksi dengan cepat, produksi hasil reaksi dapat diperoleh tanpa terkon- taminasi enzim dan enzim yang diperoleh kembali dapat dipakai lagi (Yeshajahu, 1987).

Amobilisasi enzim diklasifikasikan menjadi tipe ikatan karier, ikatan silang, dan penjeratan. Klasifikasi tersebut dapat dilihat pada gmbar 1 .

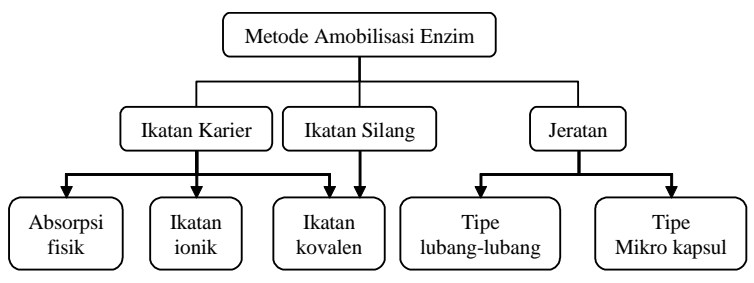

Gambar 1. Tipe-tipe Amoblisasi Enzim (Chibata, 1978)

Amobilisasi enzim dapat dianggap sebagai perubahan enzim dari larut dalam air keadaan "bergerak" menjadi keadaan "tidak bergerak" yang tidak larut. Amobilisasi mencegah difusi enzim ke dalam campuran reaksi dan mempermudah memperoleh kembali enzim tersebut dari aliran produk dengan teknik pemisahan padat atau cair yang sederhana. Ada 5 teknik (metode) amobilisasi yaitu:

1. Absorbsi enzim pada bahan pendukung

2. Pengikatan enzim secara kovalen pada bahan pendukung

3. Pengikatan silang enzim pada bahan pendukung

4. Penjeratan enzim dalam suatu bahan pendukung

5. Mikroenkapsulasi (Lee, 1996)

Secara tradisional enzim digunakan secara langsung, dengan melarutkan enzim bebas ke dalam larutan substrat. Penggunaan secara langsung dari enzim bebas pada skala besar mempunyai beberapa kelemahan antara lain:

1. Enzim bebas hanya dapat digunakan untuk satu kali proses karena enzim sukar dipisahkan dari produknya. 
2. Diperlukan proses inaktivasi enzim pada akhir reaksi, sehingga enzim dapat digunakan lebih efisien dan berulang kali. Pada suatu proses industri digunakan enzim amobil (Lee, 1996)

Kelebihan enzim amobil adalah dapat digunakan berulang-ulang, penghentian reaksi dapat dikerjakan secara cepat dengan memindahkan enzim dari larutan reaksi. Dalam banyak hal, enzim distabilkan oleh ikatan, dalam proses ini larutan tidak terkontaminasi dengan enzim. Pada proses analitik waktu paruh panjang, kecepatan peluruhan yang dapat diramalkan dan pembuatan reagen dapat dihemat.

Kappa karrageenan adalah polisakarida yang mengandung ester sulfat, lebih dari $20 \%$ bagian gula tersulfonasi tidak larut dalam air dingin. Tetapi dapat dilarutkan dengan pemanasan dan pada pendinginan berbentuk gel. Temperatur terjadinya gel dan kualitas gel tergantung pada konsentrasi polimer setara dengan jumlah dan tipe ikatan yang ada (Tosa, $d k k, 1979)$.

Kappa karrageenan dapat diperoleh dari rumput laut jenis Euchema cottonii. Unit-unit penyusun polisakarida Kappa karrageenan adalah beta-Dgalaktosa sulfat dan 5,6-anhidro-alfa-Dgalaktosa. Berat molekul Kappa karrageenan berkisar antara 100.000-800.000 (Tosa, dkk, 1979).

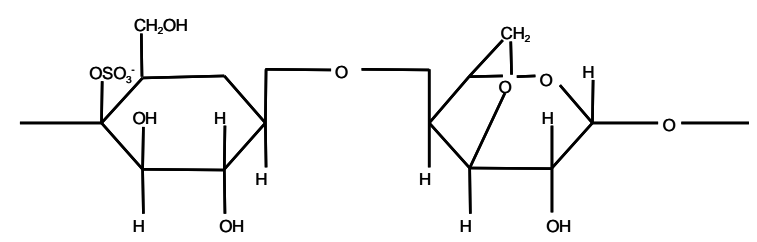

Meskipun secara teoritis penggunaan enzim amobil adalah lebih menguntungkan dari pada enzim bebas untuk proses industri, kenyataannya tidak selalu demikian. Hal ini disebabkan proses amobilisasi enzim merubah parameterparameter kinetik dan kestabilan enzim yang sangat ditentukan oleh teknik amobilisasi enzim yang digunakan (Nugroho, 1997). Pada penelitian ini bertujuan untuk membandingkan aktivitas spesifik bromelin bebas dengan bromelin amobil.

\section{METODE PENELITIAN}

Sebanyak 500 mg karagenan dilarutkan dengan $15 \mathrm{~mL} \mathrm{NaCl}$ psikologis kemudian dipanaskan sehingga suhu menjadi kira-kira $70^{\circ} \mathrm{C}$ lalu didinginkan menjadi $40^{\circ} \mathrm{C}$. Selanjutnya enzim disuspensikan dengan $\mathrm{NaCl}$ psikologis sebanyak $10 \mathrm{~mL}$ lalu dipanaskan menjadi $40^{\circ} \mathrm{C}$. Setelah keduanya mencapai suhu $40^{\circ} \mathrm{C}$ kemudian dicampur dengan pengadukan hingga rata. Lalu dituangkan ke dalam cawan petri dan kemudian didinginkan pada suhu $10^{\circ} \mathrm{C}$. Setelah dingin dicuci dengan larutan $\mathrm{NaCl}$ psikologis kemudian dipotong-potong dengan ukuran $(3 \times 3 \times 3) \mathrm{mm}$ lalu diuji aktivitasnya (Rehm, 1987). Selanjutnya enzim amobil diperoleh direaksikan dengan substrat kasein untuk menentukan unit aktivitasnya. Untuk menentukan aktivitas spesifik, dilakukan pula penentuan kadar protein dengan metoda Lowry.

\section{HASIL DAN PEMBAHASAN}

Proses amobilisasi akan berpengaruh terhadap kondisi optimum suatu enzim. Hasil penelitian menunjukkan bahwa kondisi optimum waktu inkubasi, suhu dan $\mathrm{pH}$ bromelin dari bonggol nanas sebelum amobilisasi sebesar 5 menit, $35^{\circ} \mathrm{C}$ dan 6,0, sedangkan kondisi optimum bromelin dari bonggol nanas yang telah diamobilisasi adalah 5 menit, $33{ }^{\circ} \mathrm{C}$. 
Perbedaan ini disebabkan oleh muatan molekul protein enzim dan matrik kariernya. Jika matrik bermuatan negatif maka terjadi pengumpulan ion $\mathrm{H}^{+}$pada permukaan matrik. Jika matrik bermuatan lebih positif maka terjadi pengumpulan ion $\mathrm{OH}^{-}$pada permukaan matrik. Hal ini sesuai teori yang dikemukakan Fardiaz, 1988 dan Rehm, 1987.

Tabel 1. Kondisi optimum enzim bromelin bebas dan amobil.

\begin{tabular}{lcccc}
\hline Bromelin & $\begin{array}{c}\text { Waktu } \\
\text { inkubasi } \\
\text { (menit) }\end{array}$ & $\begin{array}{c}\text { Suhu } \\
\left({ }^{\mathbf{C}} \mathbf{C}\right)\end{array}$ & $\mathbf{p H}$ & $\begin{array}{c}\text { Aktivitas } \\
\text { spesifik } \\
(\mathbf{U} / \mathbf{m g})\end{array}$ \\
\hline Bebas & 5 & 35 & 6,0 & 7,215 \\
Amobil & 5 & 33 & 6,5 & 7,215 \\
\hline
\end{tabular}

Aktivitas suatu enzim dipengaruhi oleh kondisi lingkungan, terutama $\mathrm{pH}$ dari media dan sifat protein enzim itu sendiri. Proses amobilisasikan berakibat terjadinya perubahan $\mathrm{pH}$ karena distribusi yang tidak seragam dari ion hidrogen, ion hidroksil dan substrat (Rehm, 1987, Fardiaz, 1988). Perubahan kondisi optimum antara enzim bromelin dari bonggol nanas bebas dan amobil dapat dilihat pada tabel 1 .

Salah satu keuntungan dari enzim amobil adalah bahwa enzim amobil dapat dipakai beberapa kali reaksi. Untuk bromelin dari bonggol nanas amobil aktivitas spesisfik enzim amobil dapat dipertahankan pada pemakaian dua kali. Untuk pemakaian yang ketiga kali ternyata aktivitas spesifiknya mengalami perubahan, walaupun perubahan sedikit. Hasil pemakaian bromelin amobil sebagai berikut (tabel 2):
Tabel 2. Hasil pemakaian bromelin amobil.

\begin{tabular}{cccc}
$\begin{array}{c}\text { Pemakaia } \\
\text { n Ke }\end{array}$ & $\begin{array}{c}\text { Unit } \\
\text { Aktivita } \\
\mathbf{S} \\
(\mathbf{U} / \mathbf{m L})\end{array}$ & $\begin{array}{c}\text { Aktivita } \\
\mathbf{s} \\
\text { spesifik } \\
(\mathbf{U} / \mathbf{m g})\end{array}$ & $\begin{array}{c}\text { Penuruna } \\
\text { n aktivitas } \\
\text { spesifik } \\
(\%)\end{array}$ \\
\hline 1 & 8,494 & 7,215 & 0 \\
2 & 8,494 & 7,215 & 0 \\
3 & 17,994 & 7,020 & 2,7 \\
\hline
\end{tabular}

Terjadinya penurunan daya katalitik enzim amobil ini disebabkan oleh beberapa hal, diantaranya adalah erosi matrik pada saat pembuatan enzim amobil dan pada saat reaksi enzimatis juga jenis matrik amobil yang dipakai. Metoda amobilisasi ini bermanfaat diantaranya pada bidang industri, kesehatan. Pada bidang industri, enzim amobil dapat dimanfatkan untuk berulang kali reaksi sehingga dapat menghemat anggaran pemakaian enzim. Pada bidang kesehatan, enzim amobil selain untuk pemakaian berulang kali, dapat juga untuk pemakaian pada penyembuhan penyakit dengan kemampuan atau aktivitas enzim tertentu.

\section{KESIMPULAN}

1. Enzim bromelin dari bonggol nanas dapat distabilkan dengan proses amobilisasi.

2. Aktivitas spesifik enzim bromelin amobil dapat dipertahankan pada pemakaian dua kali.

3. Kondisi optimum enzim bromelin amobil sebagai berikut:

Waktu inkubasi : 5 menit

Suhu inkubasi : $33{ }^{\circ} \mathrm{C}$

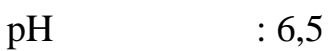

\section{UCAPAN TERIMA KASIH}

Terima kasih kami sampaikan kepada yang terhormat : 
1. Bapak Drs. Damin Sumardjo, Kepala Laboratorium Bioteknologi Fakultas Kedokteran UNDIP

2. Bapak Drs. A.S. Winoto, Apt., Koordinator Pendidikan, Bagian Kimia Fakultas Kedokteran UNDIP.

3. Ratnawati, SSi. Alumni Jurusan Kimia FMIPA UNDIP.

4. Semua pihak yang tidak dapat kami sebut satu persatu atas sumbangsih yang telah diberikan, baik berupa saran pelaksanaan penelitian, penyusunan laporan penelitian maupun penyusunan artikel ini.

Semoga budi baik beliau-beliau terbalas olehNya.

\section{DAFTAR PUSTAKA}

Anonim, 2000, Biochemical And Reagents, SIGMA USA, p. 179

Chibata, I., 1978, Immobilization Enzymes, Kodansha, Tokyo, p. 6.

Donald, K.T., Fruit and Vegetable Juice Processing Technology, $2^{\text {nd }}$, The AUI Publising, 197, p.180.

Fardiaz, F., 1988, Fisiologi Fermentasi, Kerja sama Lembaga Sumber Daya IPB, Bogor, p. 153

Harianto, E., 1996, Nanas Swadaya; Jakarta, p. 85.

Hui, Y.H., Encyclopedia of Food Science and Technology, Volume 3 John Wiley and Sons Inc., New York, 1992, p. 1747.

James, E., Bailey, D.F., Ollis, 1977, "Biochemical Engineering Fundamental, $2^{\text {nd }}$ ed, Mc Graw Hill, New York, p.180.

Lee, Byong, 1996, Fundamental of Food Biotechnology, VCH Publisher Inc, New York, p. 136.

Lehninger, 1982, Dasar-Dasar Biokimia, Erlangga, Jakarta, hlm 248-249

Mantell, SH., Matthew, JA., Mckee, R.A., 1985, Principles of plant Biotechnology : An Introduction to Genetic Engineering In Plants, Blackweell Scientific Publication: London, 1985, p. 120.
Nugroho, Tjandrawati, T., 1997, Studi Perbandingan Amobilisasi Enzim Invertase dengan Karbon Aktif dan Kalsium Alginat. Jurnal Penelitian, p. 149.

Reed, G., 1966, Food Science and Technology: Enzyme In Food Processing, Academic Press, New York And London, 1966, p. 129,146

Rehm, H.J., 1987, Biotechnology : Enzyme Technology, Volume 7a, Verlag Chemi, USA., p. 397-402.

Sumarno, Skripsi, Jurusan Kimia FMIPA UI, Depok, 1989.

Tosa T., Sato, Mori, K., Yamamoto, I., Takata, Y., Nishida and Chibata, I., 1979, Immobilization of Enzymes and Microbial Cells using Carrageenan as Matrix, Biotechnology and Bioengineering. John Wiley and Sons Inc.

Wirakusumah, E,S., 1999, Buah dan Sayur untuk Terapi, cetakan V, Penebar Semangat, Jakarta, p. 66-68.

Yeshajahu, P., Clifton, E.M. 1987, Food Analysis: Theory and Practice, $2^{\text {nd }}$ ed., Van Nostran Reinhold Company, New York, p. 322. 